\title{
Reformulation of the Epistemology of Islamic Education: Examine Noeng Muhadjir's Thoughts
}

\author{
Hamka \\ Institut Agama Islam Negeri (IAIN) Palu, Jl. Diponegoro No. 23 Palu, \\ Central Sulawesi, Indonesia \\ hamxaid@gmail.com
}

\begin{abstract}
This article shows that revelation is a barometer of the truth of science, as can be concluded from Noeng Muhadjir's thoughts. Any scientific product cannot be accepted if it is in apparent contradiction with the qat'i nash. This article is classified as qualitative research that uses a library research model. The primary data source is the works of Noeng Muhadjir, especially the article entitled, "Epistemology of Islamic Education The Theoretical-Philosophical Approach", contained in the book Reformulation of Islamic Education Philosophy, and "Education in Perspective The Koran: A Micro Review", contained in the book Education in the Perspective of the Koran. Other works are used as support. The method used in this paper is discourse analysis. The conclusion that can be drawn from the discussion results is that Noeng Muhajir takes the basis as an epistemological basis for Islamic education on the philosophy of metaphysical realism (popper) and phenomenology (ponty) as postulates of anthology and axiology. Noeng Muhadjir's ideas were driven by the spirit of bringing together science and revelation while maintaining the scientific characteristics of science and the absolute truth of revelation.
\end{abstract}

Keywords: Noeng Muhadjir, Ontology, Epistemology, Axiology, Islamic Education.

\section{Introduction}

One of the fundamental problems faced by the world of Islamic education today is the inability of Muslims to break free from the shackles of Western epistemology that dominates modern civilization today. According to Ziadudin Sardar, as Mujamil Qomar, Western epistemology is seen as a universal epistemology among Muslim and non-Muslim scientists today, putting aside other alternative epistemologies. Therefore, the world community, including Muslims, has been shaped by the West's image, which has led to what is known as epistemological imperialism. This imperialism has been running for approximately 300 years since European colonialism in the Muslim world. This condition will continue as long as Western science still 
dominates and becomes a scientific reference standard for scientists worldwide (Qomar, 2005).

The development of modern secular science based on a materialist-positivistic philosophy often results in clashes with religious dogma. This, in turn, gave birth to an ambiguous attitude among Muslim scientists who were scientifically raised by secular epistemology. As scientists, they admit (or are forced to disclose), for example, Darwin's Theory of Evolution, but as Muslims, they believe in the Theory of Creation. A concrete example that illustrates this can be seen from Nasser Mansour's research on the perception of Science teachers in Egypt in assessing the relationship between science and religion (Islam). His study shows that there is a diversity of perceptions among teachers in addressing the relationship between science and religion. Teachers sometimes create false contradictions between Islam and science because of their interpretations of the nature of Islam and science. There is a massive gap between teachers' understanding, interpretation, epistemology, and ontology of socio-scientific problems related to religion, on the one hand, and religious epistemology on the same issue, on the other (Mansour, 2010).

Another implication of Western epistemological imperialism is the birth of dualism in educational institutions in the Muslim world. General education is a centre for the development of science which is intensely coloured by secular epistemology, and religious education is a centre for the development of Islamic studies. This issue has become one of the objects of criticism by reformers such as Muhammad Abduh in Egypt (Ridha, 1344) and Ahmad Khan in India (Fazlurrahman, 1995).

Ibrahima Diallo highlighted the practice of education in the Muslim world, according to which the Islamic education system prioritizes memorizing the Koran, especially at the elementary level. This has a significant influence on the pedagogy and epistemology of Islamic education because the aspect of understanding, critical powereven though it is appreciated-is only carried out at an advanced level. Several assumptions also emerged, among others, that Islamic pedagogy and epistemology hinder students' creativity and their (critical) inquiry skills. Students are described as passive learners who are not encouraged to develop questioning skills or reject authoritative knowledge. Thus, Quranic pedagogy and epistemology in practice promote focused and decontextual learning (Diallo, 2012). Similar criticisms have also been made previously by Fazlur Rahman (Fazlurrahman, 1995). 
Creating an education system based on Islamic principles and at the same time considering the needs of modern-contemporary society is not an easy thing. For this purpose, Muslim scholars, educators, and policymakers from around the world gathered from March 31 to April 8 in 1977 for the First World Conference on Muslim Education. This conference became an important milestone in Islamic education because it was the first serious attempt to remove the dichotomy of religious and secular education from the current educational system of Islamic countries (Cook, 1999).

According to Sayyid Qutb-as quoted by Cook-science itself should not be rejected, but its acceptance must meet conditions. Islam is in harmony with the laws of the universe and the nature of existence (fitrat al-waist). Science, pure and applied, is acceptable on the condition that it does not go beyond its limits by trying to interpret what is in reality philosophically. Qutb argues that humans do not have the knowledge or the ability to know the entire order. Therefore, neither empiricism nor rationalism can be satisfactory instruments for uncovering the whole truth (Anwar, 2021). Islam emphasizes the concept of monotheism that the universe is a unity consisting of the visible and the unknown and the invisible. Life is a unity of material and spiritual energy whose separation results in imbalance or disharmony. Consequently, any system or philosophy that does not embrace the unity of the universe is incomplete and partial, separate from one another (Cook, 1999).

Thus, the most fundamental thing to bridge the gap between science and religion (Islam) and abolish the dualism of education in the Muslim world is building an epistemological framework for Islamic education, which can integrate science and revelation. In this context, one of the exciting offers to observe is Noeng Muhadjir's thoughts, particularly related to his ideas on the Epistemology of Islamic Education which uses a theoretical-philosophical approach.

This topic is, of course, not new. The literature review found several scientific works that discuss similar issues. Among other things, a book entitled Epistemology of Islamic Education written by Mujamil Qomar. This book examines the epistemology of Islamic education, which focuses on tracking the form of methods in building Islamic education science. The plans proposed by the author of this book include rational, intuitive, dialogical, comparative, and critical processes. Mujamil Qomar explains this in the introduction to his book (Qomar, 2005). 
Another work is an article written by Mansur Hery, Epistemology of Islamic Education: Tracing the Methodology of Classical Islamic College Knowledge. This paper focuses more on the epistemological aspects in the practice of classical Islamic education (Hery, 2013). The term tertiary education is also extended to the practice of non-formal education in the classical Islamic tradition. This paper is very historical in its nuances. It does not enter the discussion space about the problems of the epistemology of modern Islamic education, which is under the shadow of Western positivistic epistemological imperialism (Sunaryo, Sendayu, \& Syam, 2021).

Furthermore, the writings of Roziq Syaifudin, Epistemology of Islamic Education in Al-Ghazali and Fazlur Rahman's Eyes (Syaifudin, 2013). By the title, this article describes the comparison of thoughts between al-Ghazali and Fazlur Rahman in discussing the epistemology of Islamic education. According to the author, al-Ghazali emphasizes bayani and irfani epistemology, while Fazlur Rahman uses burhani epistemology. However, both agree that the source of knowledge is text and reality and logic and scientific analysis in their epistemology.

Another work in the form of a master's thesis written by Andi Luqmanul Qosim, entitled: Tracing the Epistemological Roots of Islamic Education (Study of the Thoughts of Sa'id Ismail Ali). This thesis highlights the epistemology of Islamic education by reinforcing its identity through cultural heritage and Islamic civilization in the form of Fiqh, Theology, Philosophy and Sufism, which are products of Islamic schools of thought traditions. This statement is based on the mapping of the epistemology of Islamic education based on these scientific streams, which are directly derived from the Qur'an and Sunnah as the authoritative sources of Islam. (Qosim, 2015).

Noeng Muhadjir's thoughts examined in this paper focus on the epistemology of "Islamic Education", not the epistemology of Islamic science. Islamic education, in this context, is seen as one of the fields of science in addition to other sciences in the Islamic studies group, such as Islamic law, theology, philosophy, and others. This distinguishes this study from several existing studies on the epistemology of Islamic education, which seem to discuss the epistemology of Islamic studies (not only Islamic education). Another difference is that the characters studied do not come from the scientific discipline background of Islamic studies, but are academics in the fields of philosophy of science, research, policy, and (general) education, so of course, they have a different point of view in viewing 
the epistemology of Islamic education compared to other figures. Others depart from the disciplines of Islamic sciences.

\section{Method}

This article is the result of research using a library research model. The primary references that the author uses in understanding Noeng Muhadjir's thoughts on the epistemology of Islamic education are his two articles. The first article, "Epistemology of Islamic Education with a Theoretical-Philosophical Approach", is contained in the book Reformulation of the Philosophy of Islamic Education (Muhadjir, 1996). While the second article, "Education in the Perspective of the Qur'an: A Micro Review", is contained in the book Education in the Perspective of the Qur'an (Muhadjir, 1999). His other works are used as support. The method used in analyzing these works is discourse analysis.

\section{Result and Discussion}

\section{Noeng Muhadjir Brief Profile}

Noeng Muhadjir, is a postgraduate professor at various universities in the fields of Philosophy of Science, Research, and Policy, since 1984. He was born in Evidence Tinggi, 13 November 1930. He completed his education at Hollandsch-Inlandsche School (HIS) at the beginning of World War II, then proceeded to Mu'allimin. In 1949, he took the junior high school extranet exam in the exact section. Furthermore, he continued to high school in the language in the morning, the same field in the afternoon and evening. In 1952, Noeng Muhadjir continued his higher education at the Faculty of Letters, Pedagogy and Philosophy at Gadja Mada University (UGM) Yogyakarta. After earning his Bachelor's degree (BA), he was assigned to be a teacher and principal for four years. In 1963, Noeng Muhadjir completed his full doctoral degree at UGM.

After serving as dean for three terms since 1966, he had the opportunity to go abroad. His overseas visits include Oklahoma State University in 1973 to study Administration for Higher Education; Harvard University for Policies Studies Planning, 1978, and in the same year preparing his dissertation research theory and methodology at Harvard University and Boston University; Ohio State University and New York University for writing the book on Human Resources Policy and Planning and many discussions for the development of Quantitative and Qualitative Research Methodology, as well as being 
involved in dissertation seminars at the School of Business, in 1987 and 1988; University of Iowa to collect as well as update references on Policy studies and Psychometrics, in 1994 and in the same year to Saint Louis University, to discuss for the development of qualitative research including its philosophy. After that, he participated in a short visit for approximately 1-2 months at Kyoto University Japan: Industrial Psychology, University Oklahoma at Norman AS: University Press, University of Klagenfurt Austria: Group dynamics, University of Linkopig: Interdepartmental research, University of Uppsala: Library studies, University of Umeo; Distance Learning, all three in Sweden, the University of Washington in Seattle: Library Studies, the University of British Colombia in Vancouver Canada: Curriculum for Higher Education, and Washington University in Saint Louis: Philosophy and morals (Muhajir, 2000).

Professional positions that Noeng Muhadjir, among others have handled: Principal of Senior High School (SLA), two private and two public, in 1960; Chief Editor of Scientific Magazine 1964-1972; Dean of the Faculty at his alma mater (UGM) 1966-1973; Director of the Research Center 1975-1979; Deputy Chairperson of the PP Muhammadiyah Board of Higher Education 1986-1990; Head of the Ministry of Education and Culture's Policy Research Quality Control Unit for Higher Education, 1993-1999; Bappenas Team for Philosophy, Basic Policy, and National Education Strategy 1999; The World Bank Staff 1999-2000 (Muhajir, 2000).

From 1990 to 1995, he served as rector of IKIP Muhamaddiyah Yogyakarta. Under his leadership, IKIP Muhamadiyah started its development to become Ahmad Dahlan University. On December 19, 1994, IKIP Muhammadiyah Yogyakarta officially became Ahmad Dahlan University, and he again served as the first chancellor for the 1995-1999 term.

There are several of Noeng Muhadjir's writings published in book form, including Education Science, Personnel Management, Manpower and Its Problems, Measurement and Assessment Techniques, Methodologies for Manpower Development and Curriculum Updating, Formal Logic and Mathematical Logic, Educational Politics, Education and Development, Social Change Theory, Advanced Research Methodology, Innovation Adoption Leadership for Community Development, Essence of Social Psychology, Science and Islamic Education, Qualitative Research Methodology, Personality Measurement, Human Resource Development Planning and Policy, and Philosophy of Science. 


\section{Philosophical Paradigm of Islamic Education}

According to Noeng Muhadjir's evaluation, Islamic education developed in Islamic universities is more influenced by positivistic epistemology, and to a lesser extent, is influenced by classical Islamic studies. A positivistic approach with behavioristic psychology dominates the methodology developed in education. Therefore, an alternative epistemology is needed to create Islamic education science that is more coherent with the texts (Qur'an and Hadith). The paradigm building offered by Noeng Muhadjir in discussing the epistemology of Islamic education is a philosophical-theoretical building, which includes statements on basic assumptions, postulates, theses, presumptions, and propositions. The philosophical basis used refers to the primary schools of philosophy: idealism, rationalism, positivism, materialism, phenomenology, existentialism, and realism. Furthermore, the relevance of the various schools of philosophy in building the epistemology of Islamic education is examined. The epistemological orientation of Islamic education offers is the integration of knowledge and revelation (Muhadjir, 1996). The term "science" in question is science, not science in the general sense of knowledge. According to Keraf, there is a difference between knowledge and science. Knowledge is the totality of thoughts, ideas, concepts, and understandings that humans have about the world and its contents, including humans and their lives. While science is the whole system of human knowledge that has been systematically standardized, or in other terms we call science (Keraf, 2001). In the view of Islam, revelation itself is a source of knowledge, in addition to the senses, reason, and intuition (Rashid, 2017).

In the following section, the philosophical paradigm of Islamic education offered by Noeng Muhadjir will be presented, including essential assumptions, ontological postulations, axiological postulations, and epistemological structures (Ikhwan, 2018).

\section{Basic Assumptions: Metaphysical Realism}

The basic assumption used as a starting point in the epistemological building of Islamic education is the metaphysical realism view that recognizes the universe's orderliness. This order is a creation of Allah swt, and the philosophy that supports this basic assumption is metaphysical realism (Muhadjir, 1996). The term assumption here by Noeng Muhadjir is interpreted as a statement of truth that is self-evident, proves its truth, and serves as a starting point for thinking. 
According to Karl Raimund Popper-the Austrian philosopher who developed the philosophy of metaphysical realism-science begins with the proposal of imaginative hypotheses, personal insights. It is unpredictable whether they can become theories. This creative hypothesis, by Noeng Muhadjir, is classified as a grand theory, not a substantive theory. This hypothesis is then tested deductively with a falsification test. In Popper's view, metaphysics is something general, universal and objective. The universal objective truth is untestable (cannot be tested). The order of the universe, for example, is untestable, which can only be proven that event $\mathrm{X}$ causes event $\mathrm{Y}$ (Popper, 2002). It is from here that Popper presents his great imaginative hypothesis, namely the deterministic theory of the regularity of the universe (Muhadjir, 1998).

The objective truth, which is called metaphysical Popper because it is untestable, by Noeng Muhadjir, is raised on the plain of transcendence to become a metaphysical truth because al-Khalik indeed created the order of the universe, the Creator because of His Omniscience, and His Omniscience. The balance of the universe: there are predators, there is death, there is decay, there is salty seawater, and many other examples present evidence of not only Omniscience but also the Omniscience of the Creator, Allah swt (Muhadjir, 2000).

\section{Ontological postulation: multistory truth}

In education, some of the material objects are normative which are value-oriented. The value itself grows with human cultures, such as democracy, justice, humanity, and so on. The positivistic research methodology does not provide room for normative studies because its ontological footing is value-free. Therefore, an ontological base is needed that can accommodate normative studies. In this context, Noeng Muhadjir is of the view that the ontological postulation of Islamic education-as its basic assumption is based on metaphysical realism-is an acknowledgement of the existence of multifaceted or multistrata truths, namely: sensual empirical truths, logical truths, ethical truths and transcendent truths that are parallel to the concept of truth, ayat, isyarah, hudan, and rahmah. Philosophies that explicitly recognize the transcendent are phenomenology (especially Merleau Ponty's monistic phenomenology) (Muhadjir, 1993) and metaphysical realism (Muhadjir, 2001).

Merleau-Ponty tried to synthesize two styles of thought that became the backbone of modern philosophy, namely rationalism and idealism, in their ontological and epistemological levels. Merleau- 
Ponty's philosophical project is to try to make the body an integral part of our minds. As we see a stone, our whole body will automatically follow or coincide to not trip over the rock. From this, we can see that what is called mind and body is an inseparable unity. A complete description of Merleau Ponty's phenomenological thought (Syamsuddin, 2010).

Noeng Muhadjir criticizes the classical Islamic view, which emphasizes that the existence of truth comes from Allah swt (Muhadjir, 1996), Allah's revelation is absolute truth. This ontological view is one of these, but epistemology and the theory of proving the truth need to be addressed. If all knowledge or whole truth in Allah swt then there is no more room for scientific work. This is a fatalistic view that must be abandoned. Therefore, two postulations must be built as a basis for epistemology: first, all that is unseen (God's Essence, the barzakh realm, heaven, hell) is the business of Allah swt and not the realm of science. While the universe with all the phenomena that are in front of us is an area of science that can be studied; second, humans are weak creatures in front of Allah's wisdom, so that humans cannot catch the absolute truth from Him, the truth of revelation is complete, but the truth of human interpretation of it is relative. Based on these two postulations, theories and theses about the universe can be built, moving from one idea to another. Conclusions about truth are probabilistic, which are very likely to be wrong and can be overturned by other theories. Noeng Muhadjir did not explain what is meant by "classical Islam", but from the context of the discussion, it can be assumed that what is meant is theology or kalam.

\section{Axiological postulation: human values and divine values}

Educational science is a normative science that must be oriented to values, both human, namely values that develop along with the development of human culture and religious values (sourced from revelation). The philosophy that supports this postulation, according to its basic assumptions, is metaphysical realism and phenomenology (Muhadjir, 1996).

\section{Epistemological thesis of Islamic education}

According to Noeng Muhadjir, the logic model developed in the Islamic world is the formal logic of Aristotle. Two weaknesses must be replaced in this model: first, formal truth verification needs to be replaced with material or substantial evidence; second, categorical proof needs to be replaced with probabilistic proof. The influence of Greek philosophy in the Islamic world raised problems: nature, 
theism-anthropocentrism, and the gift of justice. This should make us aware that the construction of the built mind-system tends to adapt the Islamic thought system to the Greek philosophical thought system, thus sharpening the qadariyah-jabariyah pole. For example, it is time to leave it. The gift of justice that emphasizes the contradiction between a single authority and a populist authority comes from the Greco-Roman democratic mindset, not the Islamic perspective (Muhadjir, 1996).

Therefore, following the ontological and axiological postulations of Islamic education described earlier, he offers a seven-point thesis on the epistemology of Islamic teaching (Muhadjir, 1996).

1. The central epistemological thesis: revelation is absolute truth;

2. Epistemological thesis I: the truth that humans can reach is only probabilistic;

3. Epistemological thesis II: the form of truth that is achieved can be sensual, logical, ethical and transcendent existence, or in the language of the Quran the structure of reality of ayat, isyarah, hudan, and rahmah. Not the four variations of truth, but the four phases or strata.

4. Epistemological thesis III: the suitable logic model in proving the truth is probabilistic logic because human reason cannot reach absolute truth;

5. Epistemological thesis IV: a probabilistic inductive proof model can be used in studying human relations with each other, as well as their relationship with nature, as long as they are not related to values (both human and divine);

6. Epistemological thesis $\mathrm{V}$ : a probabilistic deductive proof model can be used to examine the various relationships mentioned above if they are related to values.

7. Epistemological thesis VI: a probabilistic reflective logic model with a thematic or maudhu'i approach is more appropriate to study and accept the absolute truth of the nash.

The placement of revelation as the central epistemological thesis that is absolute, something that most other Muslim scientists agree on, is undoubtedly intended as the foundation for six other epistemological ideas, which are probabilistic (Rashid, 2017). This thesis animates and becomes a distinctive characteristic of the epistemology of Islamic education, which makes it different from the epistemology of secular Western education. Classical Muslim scientists 
believe that scientific truth obtained through the correct scientific method will undoubtedly be in line with prophetic truth that comes from revelation (Al-Sharaf, 2007).

The characteristic of Western/modern education is its primary dependence on the rational ability to find the truth. Reality is limited to sensual experience, scientific procedures or logical processes. Secular education seeks primarily for the development of the sensible life of each individual. In principle, it is not only Islam that claims that this kind of posture represents only one level of reality. The debate between secular scientists and Christians, for example, has been going on for centuries about whether the spiritual experience is a legitimate means of determining truth. In the expression of Islamic experience, intuition and faith are not only valid but absolutely necessary to ensure the ultimate reality, the nature of God (Cook, 1999).

\section{Reflections on Noeng Muhadjir's Thoughts}

The epistemology of Islamic education offered in Noeng Muhadjir's writings is described in simple language, to the point, but applicable, especially in building the scientific paradigm of the Philosophy of Islamic Education. The reader is not invited to explore the wilderness of philosophical debates "battle" Islamic and Western epistemology as we might find in the works of other thinkers such as Naquib al-Attas, Ismail Raji al-Faruqi, or others.

The exciting thing is that the epistemology of Islamic education offered by Noeng Muhadjir is built based on philosophical studies from various Western philosophical schools, then chooses those considered most relevant and can be integrated into the epistemology of Islamic education. So it can be said that the method used is eclectic incorporation. Eclectic because he chooses what is considered most relevant to Islamic teachings from various established philosophical schools, and incorporation because he fuses the results of his choice into the epistemology of Islamic education, as seen when he chose Karl Popper's metaphysical realism and Merleau Ponty's monistic phenomenology as the basis. The ontological postulation of Islamic education it offers.

Such an attitude, of course, cannot be separated from his background as a professor in the field of philosophy. The epistemology he offers has philosophical roots that have been tested in the scientific community. At the same time, he tries to redefine the philosophical concept in the language of religion. This is illustrated, for example, 
when he transformed Popper's idea of objective-metaphysicaluntestable truth to the level of transcendence as a form of divine creation. Similarly, when parallelizing the terms empirical-sensual, logical, ethical and transcendent with concepts ayat, isyarah, hudan, and rahmah. This shows his consistency as a scientist, as well as his Islamic integrity as a Muslim.

Noeng Muhadjir does not speak directly about the Islamization of science, nor the integration of science (Islamic studies and science). Although he is obsessed with integrating science and revelation, he offers the epistemological paradigm of Islamic education. This offer can be implemented in building educational concepts with an Islamic paradigm, not Islamizing the current secular education sciences. What he does seems to align with Sardar's view that science cannot be separated from worldviews and belief systems. Rather than "Islamicizing" the disciplines that have developed in the West's social, ethical and cultural spheres, Muslim scholars should direct their energies towards creating Islamic paradigms because, in this way, the task of meeting the urgent needs of Muslim society can be achieved implemented (Sardar, 1998). In this context, what Noeng Muhadjir did can be considered as part of an effort to create an Islamic science paradigm, especially in the discipline of Islamic education.

The epistemology of Islamic education proposed by Noeng Muhadjir uses a theoretical-philosophical approach so that the starting point is philosophy. This is different from several other Muslim thinkers who depart from the nash and then elaborate on the verses they think are the foundations of Islamic epistemology. Nidhal Guessoum, for example, asserts that the Qur'an gives us clear principles that can be viewed as 'philosophy of science', among others: (a) The Qur'an emphasizes the importance of a systematic study of nature and the universe, as in Q.S. Ali Imran (3): 190-191 and Q.S. al-Ankabut (29)::20; (b) Natural exploration, from mere observation to full scrutiny, must demonstrate the order and purpose of the cosmos; and (c) the study of nature must demonstrate a certain unity and thus lead to (more significant) faith in the Khaliq (Guessoum, 2010).

Although departing from Western philosophy (realismmetaphysics and phenomenology-monistic), the epistemology of Islamic education offered by Noeng Muhadjir still maintains the sacredness of revelation as a source of absolute truth. While the achievement of human knowledge, both as a result of interpretation of the texts and the development of exploration of nature, is in the probabilistic area whose truth is relative. With this paradigm, Muslims 
will not be trapped in the sanctification of knowledge, including knowledge sourced (interpreted) from texts. Thus, Islamic education is expected to build a harmonious and non-negotiating relationship between science and religion. Freeman Dyson describes that faith, as an essential part of human life, is rooted more profound and broader than science. Furthermore, Dyson asserted that science and religion could avoid conflict and become positive engines in the growth of humanity if science can accept giving up its imperialistic dreams and if faith can reduce its 'dogmatism' and be more open to receiving contributions from other fields of knowledge (Dyson, 2007).

\section{Conclusion}

The epistemology of Islamic education offered by Noeng Muhadjir is based on the philosophy of metaphysical realism (Popper) and phenomenology (Ponty) as postulates of ontology and axiology. While the central epistemological thesis places revelation as the source of absolute truth, it is further elaborated into six epistemological theses, namely: 1) humans can only achieve probabilistic truth; 2) the form of truth is multi strata; 3) the logic of proving the truth is probabilistic logic; 4) probabilistic inductive proof is used in studies that are not related to value; 5) probabilistic deductive evidence is used in examining matters related to values, and 6) probabilistic reflective logic with a thematic approach is more appropriate to study and accept the absolute truth of nash.

The epistemological idea of Noeng Muhadjir's Islamic education is driven by the spirit of bringing together science and revelation while maintaining the scientific characteristics of science and the absolute truth of revelation without having to contradict the two. Revelation is a barometer of the reality of science, as can be concluded from Noeng Muhadjir's thoughts. Any scientific product cannot be accepted if it is in apparent contradiction with the qat'i nash.

\section{Bibliography}

Al-Sharaf, A. (2007). Developing scientific thinking methods and Application in Islamic Education. Education, 133(3), 272-283.

Anwar, S. (2021). Pendidikan Karakter: Kajian Perspektif Tafsir fi Zilalil Qur'an. Tulungagung: STAI Muhammadiyah Tulungagung.

Cook, B. J. (1999). Islamic Versus Western Conceptions of Education: Reflections on Egypt. International Review of Education, 45(3/4), 
$339-357$.

Diallo, I. (2012). Introduction: The interface between Islamic and western pedagogies and epistemologies: Features and divergences. International Journal of Pedagogies and Learning, 7(3), 175-179. https://doi.org/10.5172/ijpl.2012.7.3.175

Dyson, F. J. U. (2007). A many-colored glass; reflections on the place of life in the universe. Charlottesville: The University of Virginia Press.

Fazlurrahman. (1995). Islam dan Modernitas; Tentang Transformasi Intelektual, Terj. Ahsin Muhammad (2nd ed.). Bandung: Pustaka.

Guessoum, N. (2010). Science, religion, and the quest for knowledge and truth: An Islamic perspective. Cultural Studies of Science Education, 5(1), 55-69. https://doi.org/10.1007/s11422-009. 9208-3

Hery, M. (2013). Epistemologi Pendidikan Islam: Melacak Metodologi Pengetahuan Perguruan Tinggi Islam Klasik. Episteme' Jurnal Pengembangan Ilmu Keislaman, 8(2), 287-304.

Ikhwan, A. (2018). Filsafat Pendidikan Islam: Memahami Prinsip Dasar. Yogyakarta: Diandra Kreatif.

Keraf, A. S. (2001). Ilmu Pengetahuan Sebuah Tinjauan Filosofi. Yogyakarta: Kanisius.

Mansour, N. (2010). Science teachers' interpretations of Islamic culture related to science education versus the Islamic epistemology and ontology of science. Cultural Studies of Science Education, 5(1), 127-140. https://doi.org/10.1007/s11422-009. 9214-5

Muhadjir, N. (1993). Ilmu Pendidikan dan Perubahan Sosial (IV). Yogyakarta: Rake Sarasin.

Muhadjir, N. (1996). Epistemologi Pendidikan Islam Pendekatan Teoritik -Filosofik. In Reformulasi Filsafat Pendidikan Islam (pp. 189-197). Yogyakarta: Pustaka Pelajar.

Muhadjir, N. (1998). Filsafat Ilmu Telaah Sistematis Fungsional Komparatif (1st ed.). Yogyakarta: Rake Sarasin.

Muhadjir, N. (1999). Pendidikan dalam Perspektif Alquran: Tinjauan Mikro. In Y. Ilyas \& M. Azhar (Eds.), Pendidikan dalam Perspektif Alquran (pp. 83-93). Yogyakarta: Lembaga Pengkajian dan Pengamalan Islam (LPPI). 
Muhadjir, N. (2000). Metodologi Penelitian Kualitatif (4th ed.). Yogyakarta: Rake Sarasin.

Muhadjir, N. (2001). Paradigma Baru Ilmu Pendidikan. Dinamika Pendidikan, 7(1), 6-12.

Muhajir, H. N. (2000). Metodologi Penelitian Kualitatif. Pendekatan Positivistik. Yogyakarta: Rake Sarisin.

Popper, K. (2002). The Logic of Scientific Discovery. London and New York: Routledge Classics. https://doi.org/10.1016/S00160032(59)90407-7

Qomar, M. (2005). Epistemologi Pendidikan Islam dari Metode Rasional hingga Metode Kritik. (S. Mahdi \& S. Bhawono, Eds.). Jakarta: Erlangga.

Qosim, A. L. (2015). Melacak Akar Epistemologi Pendidikan Islam (Studi Tentang Pemikiran Sa'id Ismail Ali). UIN Sunan Kalijaga Yogyakarta.

Rashid, F. (2017). Source of Knowledge. In F. Karim (Ed.), Philosophy of education (pp. 86-101). Islamabad: Allama Iqbal Open University.

Ridha, R. (1344). Tarikh al-Ustadz al-Syekh Muhammad Abduh, Juz II (2nd ed.). Mesir: al-Manar.

Sardar, Z. (1998). Ziadudin Sardar: Jihad Intelektual Merumuskan Parameter-parameter Sains Islam. (A. E. Priyono, Ed.). Jakarta: Risalah Gusti.

Sunaryo, S. A., Sendayu, F. S., \& Syam, A. R. (2021). Internalization of Huma Betang Cultural Values through Narrative Counseling for Elementary Education Students. JURNAL INDRIA (Jurnal Ilmiah Pendidikan Prasekolah Dan Sekolah Awal), 6(1).

Syaifudin, R. (2013). Epistemologi Pendidikan Islam Dalam Kacamata Al-Ghazali dan Fazlur Rahman. Episteme' Jurnal Pengembangan Ilmu Keislaman, 8(2), 287-304. https://doi.org/10.21274/epis.2013.8.2.323-346

Syamsuddin, M. (2010). Kritik Fenomenologis Merleau-Ponty atas Filsafat Pengetahuan. Jurnal Tsaqafah, 6(2), 214-224. 